\title{
Prevalence of Oral Potentially Malignant Disorders and Awareness on Oral Cancer among Dental Patients
}

\author{
Ahmad Moin N ${ }^{1}$, Zulkiffli S ${ }^{1}$, Kallarakkal TG ${ }^{2}$ \\ ${ }^{1}$ Faculty of Dentistry, University of Malaya, Kuala Lumpur, Malaysia. \\ ${ }^{2}$ Department of Oral and Maxillofacial Clinical Sciences, Faculty of Dentistry, University of Malaya, Kuala \\ Lumpur, Malaysia.
}

\begin{abstract}
The burden of head and neck squamous cell carcinoma (HNSCC) is increasing globally with 600,000 new cases being reported annually: A great proportion of these are oral squamous cell carcinomas (OSCCs) which are preceded by oral potentially malignant disorders (OPMDs). The aim of our study was to assess the prevalence of OPMDs among adult Malaysian dental patients with and without risk habits. The objectives of this study were i) to determine the prevalence of OPMDs among dental patients who were tobacco smokers ii) to determine the prevalence of OPMDs among dental patients who were alcohol users iii) to determine the prevalence of OPMDs among dental patients without any risk habits iv) to determine the awareness on oral cancer among dental patients with and without risk habits. Materials and methods: This was a cross sectional observational study, carried out at Faculty of Dentistry, University of Malaya. A conventional oral examination was conducted by two investigators who were trained and calibrated prior to the survey. Participants were administered a questionnaire that was pre-tested in a previous study. 83 subjects were recruited into the study. Leukoplakia was the only OPMD detected in our study with a prevalence of $10.8 \%$. All patients diagnosed with leukoplakia were males $(P<0.05)$. A significant association between the prevalence of OPMDs and risk habits was found. There was a general lack of awareness among smokers regarding alcohol as an aetiological agent for oral cancer. A significant proportion of subjects who smoked were unaware of early signs of oral cancer.
\end{abstract}

Keywords: OPMD, smoking, alcohol, leukoplakia, oral cancer awareness, mouth self-examination

\section{INTRODUCTION}

The prevalence of oral mucosal lesions (OML) in different populations shows a great variability. Reports about the prevalence of OML are based on studies on different populations such as the elderly, children, and patients visiting dental schools, college students, hospitalized patients, misusers and normal population(1). Such surveys provide an accurate description of the epidemiology of OML. In Malaysia, several surveys of OML targeting specific subject groups have been carried out. These include reports on the prevalence of selected OMLs among Indians and Malays, in an army population and among the older age groups. Hospital-based surveys involving multi-ethnic groups have also been reported. A national epidemiological survey of OML in Malaysia reported the prevalence of OML to be $9.7 \%(2)$. 
Oral cancer is the 6th common cancer worldwide with majority of them being oral squamous cell carcinoma (OSCC). OSCC is among the most common type of cancers in Malaysia (i.e., 9th and 13th respectively for males and females). The incidence varies worldwide with the variation being attributable to risk habits, exposure to different types of chemical or biological carcinogens and possibly the diverse genetic makeup of the different ethnic groups. Majority of the OSCCs are preceded by oral potentially malignant disorders (OPMDs). OPMDs are a family of morphological alterations amongst which some may have an increased potential for malignant transformation. Potentially malignant disorders of the oral mucosa are also indicators of risk of likely future malignancies elsewhere on the (clinically normal appearing) oral mucosa (3). Leukoplakia, erythroplakia, oral lichen planus (OLP) and oral sub mucous fibrosis (OSMF) are the more common OPMDs when we reviewed the literature dealing with CNAs that drive oral precursor lesions to the invasive tumors (4). Results showed a sequential accumulation of genetic changes from oral precursor lesions to invasive tumors. With the disease progression, accumulation of genetic changes increases in terms of frequency, type and size of the abnormalities, even on different regions of the same chromosome. Gains in $3 q(36.5 \%$. Environmental stresses such as smoking, alcohol drinking and betel-quid chewing play a critical role in causing OPMD and OSCC when we reviewed the literature dealing with CNAs that drive oral precursor lesions to the invasive tumors. (4) Results showed a sequential accumulation of genetic changes from oral precursor lesions to invasive tumors. With the disease progression, accumulation of genetic changes increases in terms of frequency, type and size of the abnormalities, even on different regions of the same chromosome. Gains in $3 q(36.5 \%)$.

Tobacco use is a great health problem. It is associated with high levels of morbidity and mortality all over the world. Five million people die from tobaccorelated diseases every year in the world, particularly in developing countries. Tobacco and alcohol use have been established as risk factors for the development of OPMDs(4)we reviewed the literature dealing with CNAs that drive oral precursor lesions to the invasive tumors. Results showed a sequential accumulation of genetic changes from oral precursor lesions to invasive tumors. With the disease progression, accumulation of genetic changes increases in terms of frequency, type and size of the abnormalities, even on different regions of the same chromosome. Gains in 3q $36.5 \%$. Researchers have reported various lesions in association with tobacco use such as leukoplakia, smoker's melanosis, and OSMF.
Ahmadi-Motamayel et al. (2013) stated that 100\% smokers and $35.27 \%$ non-smokers had black hairy tongue (coated tongue); and $2.33 \%$ of smokers had nicotinic stomatitis in comparison to non-smokers (5). Risk habits principally tobacco use (cigarette smoking, cigar smoking, pipe smoking, bidi smoking, tobacco chewing, smokeless tobacco) and alcohol drinking, influence the development of OPMDs or OSCC either individually or synergistically (5). An independent role for tobacco use and an unclear role for alcohol consumption for the development of OPMDs and OSCC has been established. Excess consumption of any type of alcohol (spirits, beer or wine) has been thought to increase the risk for oral cancer, although this is believed to be much higher for the pharynx than for the mouth. All types of alcoholic beverages are implicated, although there is some controversy as to which beverages carry the greatest risk(6).

A conventional oral examination (COE) has traditionally been the preferred approach for detection of OML. It is a non-invasive technique that can be performed quickly by a multitude of healthcare professionals without any additional expense to the patient. It has been reported that a COE that includes visual examination and digital palpation has a sensitivity and specificty of $74 \%$ and $99 \%$ when used as a screening tool for detection of OSCC(6).

Although the cause of OPMDs and OSCCs have been established, lack of awareness among patients result in delayed diagnosis and treatment for oral cancer (7). In the United Kingdom, only $56 \%$ of the population were aware of oral cancer(8). A study conducted among university students in Malaysia reported that $92 \%$ of the 200 subjects were aware of the early signs of oral cancer(9). The primary aim of our study was to assess the prevalence of OPMDs among adult Malaysian dental patients with and without risk habits. The main objectives of this study were i) to determine the prevalence of OPMDs among dental patients who were tobacco smokers ii) to determine the prevalence of OPMDs among dental patients who were alcohol users iii) to determine the prevalence of OPMDs among dental patients without any risk habits iv) to determine the awareness on oral cancer among dental patients with and without risk habits.

\section{MATERIALS AND METHODS}

This was a cross sectional observational study that was limited to subjects seeking dental treatment at the Primary Care Department, Faculty of Dentistry, University of Malaya. The study was approved by the local ethics committee (ethics number DF OS 1512/0044) at the Faculty of Dentistry, University of 
Malaya. 83 subjects who were 18 years and older were recruited into the study. All subjects were provided with written information consent prior to participation in the study.

A calibration exercise for the investigators was conducted by the supervisor on a single day prior to the survey using an established training program consisting of lectures on $\mathrm{COE}$, white and red oral mucosal lesions, pigmented lesions, ulcers, swellings, and calibration assessments. There were four calibration assessments in sequence consisting each of 20 digitalized images. Each calibration assessment was followed by discussions on the interpretation of the images. The examiners were allowed to examine the subjects only if they had scored $80 \%$ marks in the final calibration assessment.

A questionnaire (Figure 1 and 2) on sociodemographic characteristics, tobacco and alcohol use was administered to all the subjects. The type of tobacco smoked (cigarettes, bidi, etc) and the type of consumed alcohol (beer, wine, toddy, etc) were recorded. The number of years the subject smoked tobacco and consume alcohol were also recorded. Ex-smokers were distributed in the following way: those who had not smoked for more than 2 years were considered as non-smokers; those who had not smoked for less than 2 years were considered as smokers. The same definition was applied for alcohol consumption.

RN

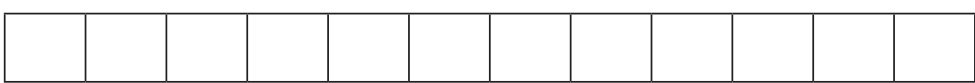

\section{PERSONAL DETAILS}

$1 . \quad$ Date of birth :

2. Gender (Please tick $\checkmark$ where applicable)

$\square$ Male
Ethnicity (Please tick $\checkmark$ where applicable)

3.

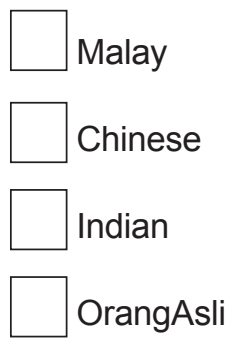

4. Marital status (Please tick $\checkmark$ where applicable)

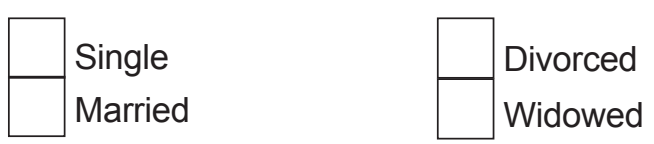

5. Average family income per month :

6. How many years of schooling

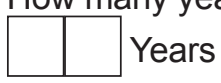

7. Occupation :

Figure 1: Patient Information Sheet

A structured questionnaire (Figure 3) that consisted of four close ended questions was also administered to the subjects to assess their awareness regarding oral cancer. This questionnaire was developed, its contents face-validated and pretested prior to its use in the field in a previous study (9). Respondents were asked questions regarding awareness of oral cancer (whether they have heard 
1) Smoking habit (Please tick $P$ where applicable)

a) Type of tobacco smoked

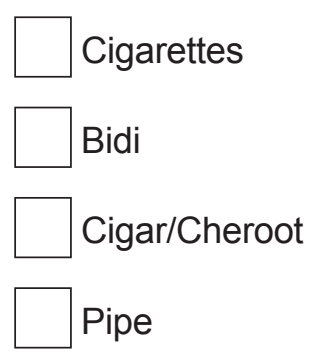

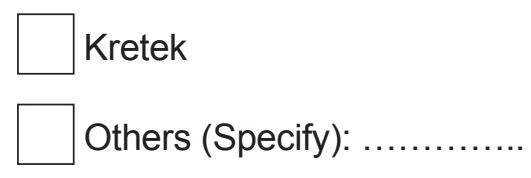

2) Alcohol habit (Please tick $\checkmark$ where applicable)

a) Type of alcohol consumed

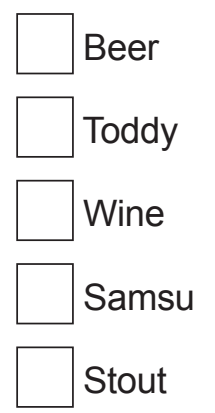

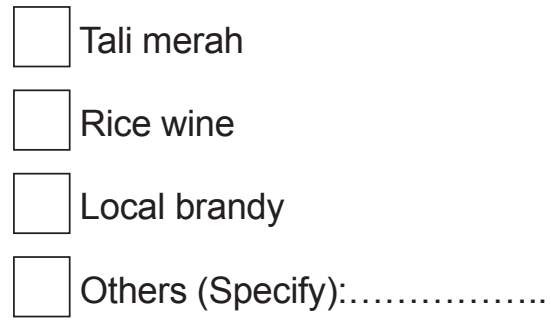

b) Number of $\mathrm{ml}$ of alcohol consumed per week:

c) Number of years drank:

3) Quid chewing habit (Please tick $\checkmark$ where applicable)
a) Number of quid per day:
b) Number of years:
c) Ingredients contained in the quid:

Figure 2: Assessment Of Risk Habits

of it previously), causes of oral cancer (particularly its association with alcohol and tobacco use), mouth self-examination, and the early signs of oral cancer.

A COE aided by dental operatory light, mouth mirrors, and gauze was conducted by the two investigators. Digital images of all the lesions identified in the subjects were obtained.

Consensus on the final diagnosis was based on the review of the digitalized images of OMLs with the supervisor.

The diagnostic criteria for target lesions such as oral cancer, leukoplakia, erythroplakia, OLP, OSMF, acute candidiasis and smoker's palate were based on the recommendations of the WHO in 1980(2). The diagnostic criteria for leukoplakia and erythroplakia was based on the revised definition and criteria arising from a workshop coordinated by the WHO Collaborating Centre for Oral Cancer and Precancer in the UK for issues related to terminology, definitions and classification of oral pre-cancer(5).

All the data obtained from this research were analyzed using SPSS version 12.0. For comparison of categorical variables (particularly for OPMDs) between risk habit groups, the Chi-square and Fisher's exact tests were used. Logistic regression analysis was used if the assumption of Chi-square test was not fulfilled. 
1) Pernahkah anda mendengar tentang kanser mulut sebelum ini?

Have you heard of mouth cancer before this?

$1=$ YA/YES $2=$ TIDAK/NO

*jika YA, teruskan menjawab soalan berikut *if YES, continue answering

**jika TIDAK, berhenti menjawab, terima kasih di atas kerjasama anda

**if NO, thank you for your cooperation, please do not answer further

2) Di antara berikut, tabiat manakah yang biasanya dikaitkan dengan kanser mulut?

Among the list below, which of these habits are usually related to mouth cancer?

(ANDA BOLEH TANDA LEBIH DARI SATU)

(YOU CAN TICK MORE THAN ONE)

\begin{tabular}{|l|c|}
\hline $\begin{array}{l}\text { Pengambilan gula berlebihan } \\
\text { Excess in sugar }\end{array}$ & $($ ) \\
\hline $\begin{array}{l}\text { Menguyah sireh } \\
\text { Betel quid chewing }\end{array}$ & $(\quad)$ \\
\hline $\begin{array}{l}\text { Makan makanan pedas } \\
\text { Eating spicy food }\end{array}$ & $(\quad)$ \\
\hline $\begin{array}{l}\text { Pendedahan berlebihan kepada sinaran uv/matahari } \\
\text { Excessive exposed to uv rays/sun }\end{array}$ & $(\quad)$ \\
\hline $\begin{array}{l}\text { Merokok } \\
\text { Smoking }\end{array}$ & $(\quad)$ \\
\hline $\begin{array}{l}\text { Pengambilan alcohol berlebihan } \\
\text { Excessive alcohol intake }\end{array}$ & $(\quad)$ \\
\hline $\begin{array}{l}\text { Jarang gosong gigi } \\
\text { Infrequently brushing teeth }\end{array}$ & \\
\hline
\end{tabular}

3) Yang manakah antara berikut merupakan tanda-tanda awal kanser mulut?

What are the early sign of mouth cancer?

\begin{tabular}{|l|c|c|c|}
\hline & YA/YES & TIDAK/NO & $\begin{array}{c}\text { TIDAK } \\
\text { TAHU/ } \\
\text { DONOT } \\
\text { KNOW }\end{array}$ \\
\hline $\begin{array}{l}\text { Tompok putih / merah di dalam mulut } \\
\text { White / red spot inside the mouth }\end{array}$ & $($ ) & $($ ) & $($ ) \\
\hline $\begin{array}{l}\text { Ulcer yang tidak sembuh dalam masa 2 minggu } \\
\text { Unhealed ulcer within 2 weeks }\end{array}$ & $($ ) & $($ ) & $($ ) \\
\hline $\begin{array}{l}\text { Gusi berdarah } \\
\text { Gum bleeding }\end{array}$ & $($ ) & $($ ) & $($ ) \\
\hline
\end{tabular}

4) Tahukah anda, pemeriksaan sendiri mulut adalah salah satu langkah pencegahan untuk kanser mulut?

Do you know that self examination is one of the preventive step for mouth cancer?

$1=$ YA/YES $\quad 2=$ TIDAK $/ N O \quad 3=$ TIDAK TAHU/DO NOT KNOW

Figure 3: Close ended questions to assess their awareness regarding oral cancer 


\section{RESULTS}

Figure 4 shows the prevalence of oral mucosal lesions in our study subjects. This study had a total of 83 subjects. OMLs in our study subjects were broadly classified into seven different categories. They included OPMDs, normal anatomical variations, reactive lesions, pigmented lesions, tongue lesions, ulcers and others. Leukoplakia was the only OPMD detected with a prevalence of $10.8 \%$ among the subjects. The most common form of normal anatomic variation seen was linea alba which was recognized in 32 subjects (38.6\%).

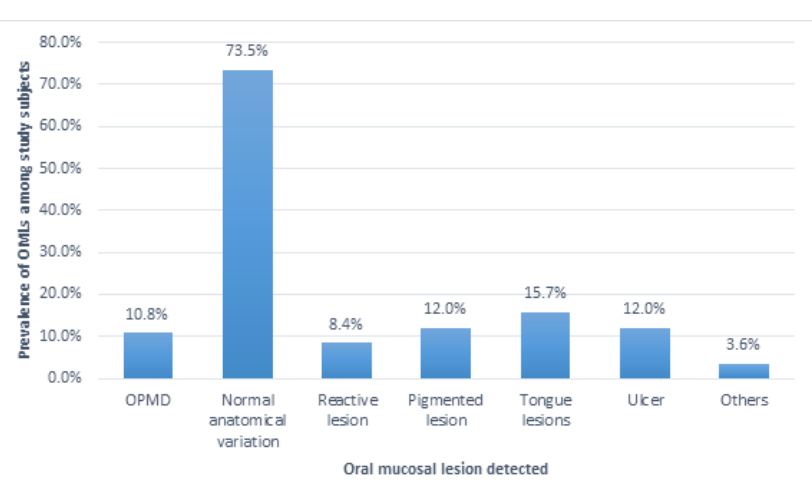

Figure 4 : Prevalence of OMLs among study subjects

Statistical analysis in Table 1 showed a significant association between certain sociodemographic characteristics of patients with prevalence of OPMDs. All patients with leukoplakia were males $(p<0.05)$. Similarly there was also a significant association between the level of occupation of the subjects and the prevalence of leukoplakia $(p<0.05)$. There was no significant association with the prevalence of leukoplakia and other sociodemographic characteristics such as age, ethnicity, marital status, education level, and income status of the study subjects.

Table 1: Association between sociodemographic characteristics and OPMDs among the study subjects

\begin{tabular}{lccc}
\hline \multicolumn{3}{c}{ OPMD } \\
\hline $\begin{array}{l}\text { Sociodemographic } \\
\text { characteristics }\end{array}$ & $\begin{array}{c}\text { Yes } \\
\mathbf{n}(\%)\end{array}$ & $\begin{array}{c}\text { No } \\
\mathbf{n}(\%)\end{array}$ & $\mathbf{p}$ value \\
\hline Age & & & \\
$<20$ & $0(0.0)$ & $2(2.7)$ & $0.173^{*}$ \\
$21-30$ & $3(33.3)$ & $38(51.4)$ & \\
$31-40$ & $3(33.3)$ & $6(8.1)$ & \\
$51-60$ & $2(16.7)$ & $10(13.5)$ & \\
$>60$ & $1(11.1)$ & $12(16.2)$ & \\
Gender & & & \\
Male & $9(100.0)$ & $41(55.4)$ & 0.010 \\
Female & $0(0)$ & $33(44.6)$ & \\
& & &
\end{tabular}

\begin{tabular}{lccc} 
Ethnicity & & & \\
Malay & $4(44.4)$ & $31(41.9)$ & $0.068^{*}$ \\
Chinese & $2(22.2)$ & $34(45.9)$ & \\
Indian & $3(33.3)$ & $8(10.8)$ & \\
Others & $0(0.0)$ & $1(1.4)$ & \\
& & & \\
Marital status & & & \\
$\quad$ Single & $4(44.4)$ & $37(50.0)$ & $0.626^{*}$ \\
$\quad$ Married & $5(55.5)$ & $36(48.6)$ & \\
Divorced & $0(0.0)$ & $1(1.4)$ & \\
Education level & & & \\
Primary school & $0(0.0)$ & $8(10.8)$ & $0.310^{*}$ \\
Secondary school & $5(55.6)$ & $11(14.9)$ & \\
Tertiary & $4(44.4)$ & $55(74.3)$ & \\
& & & \\
Occupation & & & \\
$\quad$ Student & $0(0.0)$ & $27(36.5)$ & $0.020^{*}$ \\
Professional & $3(33.3)$ & $17(23.0)$ & \\
Non-professional & $6(66.7)$ & $30(40.5)$ & \\
Income & & & \\
$<2000$ & $0(0.0)$ & $6(8.1)$ & $0.987^{*}$ \\
2000-5000 & $8(88.9)$ & $53(71.6)$ & \\
$>5000$ & $1(11.1)$ & $15(20.3)$ & \\
\hline
\end{tabular}

*Simple logistic regression was used as assumption of Chi-square test was not fulfilled

Table 2 shows a significant association between the prevalence of OPMDs and risk habits. The synergistic effects of smoking and alcohol drinking weremorepronouncedascompared tosmokingalone.

Table 2: Risk estimate for study subjects with risk habits for OPMD

\begin{tabular}{lcc}
\hline Risk habits & $\mathrm{RR}(95 \% \mathrm{Cl})$ & $\mathrm{p}$ value \\
\hline None & - & - \\
Smoking only & $5.217(1.422,19.142)$ & $\mathbf{0 . 0 1 2}$ \\
Drinking only & - & - \\
Smoking + Drinking & $5.429(1.720,17.136)$ & $\mathbf{0 . 0 2 5}$ \\
\hline
\end{tabular}

Figure 5 and 6 shows the awareness of our study subjects regarding smoking and alcohol misuse as a cause of oral cancer. Most of the subjects who did not have any risk habits $(80.0 \%)$ were aware that smoking caused oral cancer, but only $50 \%$ of them were aware that alcohol is a causative factor of oral cancer. Most of the subjects who smoked (60.9\%) knew that smoking caused oral cancer, but many of the smokers $(69.6 \%)$ did not know that alcohol was a cause for oral cancer. However, subjects who only drank alcohol were aware that alcohol caused oral cancer $(p<0.05)$ and many of them $(87.0 \%)$ were also aware that smoking is a causative factor of oral cancer. There seemed to be a trend among those who smoked and drank alcohol, whereby majority of them didn't know that smoking $(57.1 \%)$ and alcohol $(85.7 \%)$ caused oral cancer. 


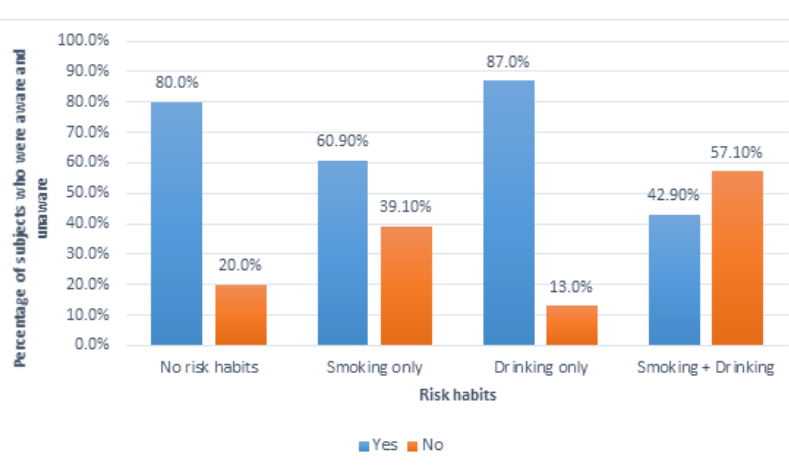

Figure 5: Awareness regarding smoking as a cause of oral cancer among the study population

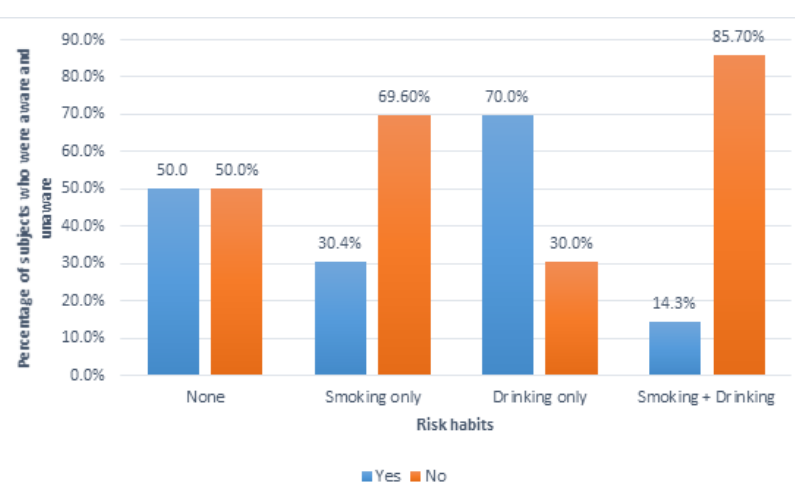

Figure 6: Awareness regarding alcohol as a cause of oral cancer among the study population

Figure 7 shows the awareness regarding mouth self-examination as an early diagnostic tool for oral cancer among the study population. A significant proportion of our study subjects who were smokers were not aware of the potential of mouth selfexamination as an early diagnostic tool for detection of oral cancer. On the contrary $60.9 \%$ of the subjects who practiced only alcohol drinking were aware of the benefits of mouth self-examination for early detection of oral cancer but this was not statistically significant.

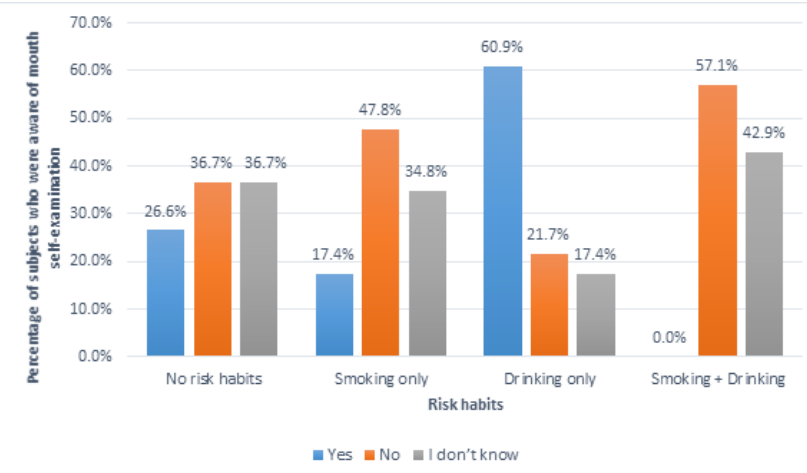

Figure 7: Awareness regarding mouth self-examination as an early diagnostic tool for oral cancer among the study population

Table 3 shows the awareness regarding early signs of oral cancer among the study population. There was a significantly decreased awareness among smokers regarding white/red spot inside the mouth as an early sign of oral cancer. This was in contrast to highly significant increased awareness among subjects who only had alcohol drinking as a risk habit. Most of the subjects with no risk habits $(43.3 \%)$ were aware that white/red spot in the mouth was as early sign of oral cancer. Smokers also exhibited significantly decreased awareness regarding chronic oral ulcers as early signs of oral cancer. Majority of the subjects with no risk habits

Table 3: Awareness regarding early signs of oral cancer among the study population

\begin{tabular}{|c|c|c|c|c|c|c|c|c|c|c|c|c|}
\hline \multirow[t]{3}{*}{ Risk habit } & \multicolumn{4}{|c|}{ White/ red spot inside mouth } & \multicolumn{4}{|c|}{ Ulcer $>2$ week } & \multicolumn{4}{|c|}{ Bleeding gum } \\
\hline & \multirow{2}{*}{$\begin{array}{c}\text { Yes } \\
n(\%)\end{array}$} & \multirow{2}{*}{$\begin{array}{c}\text { No } \\
\mathrm{n}(\%)\end{array}$} & \multirow{2}{*}{$\begin{array}{c}\begin{array}{c}\text { I don't } \\
\text { know }\end{array} \\
\text { n (\%) }\end{array}$} & \multirow[t]{2}{*}{$\begin{array}{c}\text { Total } \\
\text { (p value) }\end{array}$} & \multirow{2}{*}{$\begin{array}{c}\text { Yes } \\
\mathrm{n}(\%)\end{array}$} & \multirow{2}{*}{$\begin{array}{c}\text { No } \\
\text { n (\%) }\end{array}$} & \multirow{2}{*}{$\begin{array}{c}\begin{array}{c}\text { I don't } \\
\text { know }\end{array} \\
\text { n (\%) }\end{array}$} & \multirow[t]{2}{*}{$\begin{array}{c}\text { Total } \\
\text { (p value) }\end{array}$} & \multirow{2}{*}{$\begin{array}{c}\text { Yes } \\
\mathrm{n}(\%)\end{array}$} & \multirow{2}{*}{$\begin{array}{c}\text { No } \\
\mathrm{n}(\%)\end{array}$} & \multirow{2}{*}{$\begin{array}{c}\begin{array}{c}\text { I don't } \\
\text { know }\end{array} \\
\text { n (\%) }\end{array}$} & \multirow[t]{2}{*}{$\begin{array}{c}\text { Total } \\
\text { (p value) }\end{array}$} \\
\hline & & & & & & & & & & & & \\
\hline None & $\begin{array}{c}13 \\
(43.3)\end{array}$ & $\begin{array}{c}8 \\
(26.7)\end{array}$ & $9(30.0)$ & $\begin{array}{c}30 \\
(0.558)\end{array}$ & $\begin{array}{c}21 \\
(70.0)\end{array}$ & $\begin{array}{c}6 \\
(20.0)\end{array}$ & $3(10.0)$ & $\begin{array}{c}30 \\
(0.095)\end{array}$ & $\begin{array}{c}10 \\
(33.3)\end{array}$ & $\begin{array}{c}12 \\
(40.0)\end{array}$ & $8(26.7)$ & $\begin{array}{c}30 \\
(0.568)\end{array}$ \\
\hline $\begin{array}{l}\text { Smoking } \\
\text { only }\end{array}$ & $\begin{array}{c}2 \\
(8.7)\end{array}$ & $\begin{array}{c}10 \\
(43.5)\end{array}$ & $\begin{array}{c}11 \\
(47.8)\end{array}$ & $\begin{array}{c}23 \\
(0.003)\end{array}$ & $\begin{array}{c}7 \\
(30.4)\end{array}$ & $\begin{array}{c}9 \\
(39.2)\end{array}$ & $7(30.4)$ & $\begin{array}{c}23 \\
(0.014)\end{array}$ & $\begin{array}{c}7 \\
(30.4)\end{array}$ & $\begin{array}{c}11 \\
(47.8)\end{array}$ & $5(21.8)$ & $\begin{array}{c}23 \\
(0.714)\end{array}$ \\
\hline Drinking only & $\begin{array}{c}16 \\
(69.6)\end{array}$ & $\begin{array}{c}4 \\
(17.4)\end{array}$ & $3(13.0)$ & $\begin{array}{c}23 \\
(0.001)\end{array}$ & $\begin{array}{c}17 \\
(73.9)\end{array}$ & $\begin{array}{c}4 \\
(17.4)\end{array}$ & $\begin{array}{c}2 \\
(8.7)\end{array}$ & $\begin{array}{c}23 \\
(0.083)\end{array}$ & $\begin{array}{c}13 \\
(56.6)\end{array}$ & $\begin{array}{c}7 \\
(30.4)\end{array}$ & $3(13.0)$ & $\begin{array}{c}23 \\
(0.081)\end{array}$ \\
\hline $\begin{array}{l}\text { Smoking + } \\
\text { Drinking }\end{array}$ & $0(0.0)$ & $\begin{array}{c}6 \\
(85.7)\end{array}$ & $1(14.3)$ & $\begin{array}{c}7 \\
\left(0.593^{*}\right)\end{array}$ & $0(0.0)$ & $\begin{array}{c}6 \\
(85.7)\end{array}$ & $1(14.3)$ & $\begin{array}{c}7 \\
\left(0.127^{\star}\right)\end{array}$ & $\begin{array}{c}1 \\
(14.3)\end{array}$ & $\begin{array}{c}5 \\
(71.4)\end{array}$ & $1(14.3)$ & $\begin{array}{c}23 \\
\left(0.655^{\star}\right)\end{array}$ \\
\hline
\end{tabular}

*Simple logistic regression was used as assumption of chi-square test was not fulfilled 
$(40.0 \%)$ and smokers (47.8\%) had increased awareness regarding bleeding gums as not an early sign of oral cancer. There seemed to be a decreased awareness amongst the subjects who smoked and drank alcohol regarding presence of white/red spot inside the mouth $(85.7 \%)$ and ulcer for more than 2 weeks $(85.7 \%)$ as an early sign of oral cancer.

\section{DISCUSSION}

Prevalence studies follow different methodological patterns that vary with respect to patient selection, diagnostic criteria and different ages of assessment for diagnosis. They may show considerable geographic variation and differences between the current and published data from other regions awareness and knowledge of oral cancer (10). Mean age of the respondents was 21.5 and the age ranged from 18 to 27 years. The majority of the respondents were aware of oral cancer (92.0\%). The prevalence of OMLs in this study was found to be $12.05 \%$. The observed prevalence was derived after excluding lesions that were grouped under the category of normal anatomical variations which included linea alba, torus palatinus, torus mandibularis, lingual varicosities and physiological/racial pigmentation. The prevalence rate of OML in our study was found to be greater than reported by Zain et al. as part of a nationwide oral mucosal survey(2). This variation in the reported prevalence may be explained by the fact that the current study was a sample of convenience which included only dental patients with and without risk habits while in the study reported by Zain et al, the subjects were randomly sampled from the national population.

OPMDs precede the development of OSCC. Leukoplakia, erythroplakia, OLP and OSMF are the more common OPMDs(11). Leukoplakia was the only OPMD identified in our study with a prevalence rate of $10.8 \%$. This was higher than the earlier reported prevalence rates of $1.84 \%$ and $0.97 \%$ respectively in the Malaysian population. Based on the examination of 20,333 individuals in Sweden, Axell et al. reported that the prevalence of leukoplakia could vary between $0.7 \%$ and $24.8 \%$ depending on the clinical criteria used where entities such as leukoedema, snuffinduced lesions, frictional keratosis, cheek biting and lip biting could have contributed to the range of prevalence(2). In the present study, the investigators were trained and calibrated to precisely differentiate leukoplakia from entities such as leukoedema, lip biting, cheek biting and frictional keratosis. The increased prevalence rates for leukoplakia in our study may be explained by the fact that $63.85 \%$ of our patients had high risk habits.
Tobacco and alcohol use have been established as risk factors for the development of OPMDs. It has been reported that persons who used tobacco - smoked, chewed or both-develop most lesions particularly leukoplakia, with an annual incidence rate ranging from $5.2 / 1000$ to $30.2 / 1000$ depending on the pattern of use. Non-users of tobacco develop the fewest lesions ranging from $0.6 / 1000$ to $5.8 / 1000$ per year. The findings from our study are concordant with these observations. None of our subjects without any risk habits manifested OPMDs. Subjects who only smoked were 5.217 times more likely to get OPMDs as measured by relative risk (RR 5.217, $95 \% \mathrm{Cl} 1.422-19.142)$. As for those who smoked and drank alcohol, the increased risk for OPMDs was 5.429 as measured by relative risk (RR $5.429,95 \% \mathrm{Cl}$ 1.720-17.136). Smoking is recognized as a health problem worldwide with tobacco users at increased risk of developing many diseases(12). In the current study cigarette smoking was the most common risk habit observed with majority of the smokers being males $(96.4 \%)$.

In developed nations, leukoplakias are usually found in middle-aged and elderly people. A majority of these lesions occur between the fourth and seventh decades of life, while in the developing world, they tend to occur at least 5-10 years earlier (12). Studies on the incidence of OPMDs from India have shown that $95-98 \%$ of leukoplakias are seen in males. Similar results have been reported among tobacco users from Saudi Arabia and China(3/13). The study of prevalence and distribution of oral mucosal lesions in adult Turkish population identified that leukoplakia was detected 4 times more often in men than in women (Cebeci et al., 2009). The results of our study are comparable with the previous studies as all subjects diagnosed with leukoplakia in our study were males with an age range varying between 21 to $>60$ years.

Globally, oral and pharyngeal cancers have been rated as the 6th most common cancer in men and 9th in women. A majority of these cancers occur in developing countries of South and South East Asian region (14). Early detection of OSCC makes them more amenable to treatment, thus reducing morbidity and allowing the greatest chance of cure. Lack of public awareness has been reported to be a significant factor in delaying referral and treatment of oral cancer(15). It has been reported that public awareness of oral cancer in the USA was low with less than a quarter of people naming alcohol or tobacco as risk factors(16).

Awareness regarding risk habits associated with oral cancer and early detection of oral cancers plays a vital part in decreasing the occurrence of oral cancer in a population. Apart from determining 
the prevalence of OPMDs, our study also aimed to determine the awareness of our subjects regarding the matters aforementioned. It was observed that most of the subjects who had risk habits were aware that their habit was a cause of oral cancer. $60.9 \%$ of smokers and $69.6 \%$ of alcohol consumers knew that smoking and alcohol were causes of oral cancer respectively. Although $60.9 \%$ of smokers knew that smoking was a risk of oral cancer, it was observed that there was a general lack of awareness among smokers regarding misuse of alcohol as an aetiological agent for oral cancer. $69.9 \%$ of the smokers did not know that alcohol was a cause of oral cancer. The results were in concordance with a similar study in the United Kingdom where only $19 \%$ of the study subjects were aware of the association between oral cancer and alcohol misuse. A previous study by Ghani et al on oral cancer awareness among a selected Malaysian population reported a lack of awareness among the subjects regarding risk habits such as alcohol misuse and betel quid chewing(a). As for the subjects who drank and smoked, there was a greater proportion that was not aware that smoking and alcohol consumption caused oral cancer. These findings are important as oral health education can be targeted to this high-risk group in order to provide knowledge and awareness regarding the association of high risk habits associated with oral cancer.

Self-examination has been effectively employed for early detection of breast cancer and may be effectively adopted for early detection of oral cancer(17). A considerable proportion of our subjects were not aware of mouth self-examination. Most of the subjects, either were not aware of the methods to do a mouth self-examination, or they had never heard of mouth self-examination before.

A significant proportion of our subjects who smoked were not aware that a white/red spot inside the mouth was an early sign of cancer. However, a significant number of subjects who only had alcohol consumption as a risk habit knew that white/red spot inside the mouth was an early sign of cancer. None of our subjects who smoked and drank alcohol knew that white/red spot inside the mouth and ulcer which persisted for more than two weeks were early signs of oral cancer. Ghani et al. also observed similar findings in her selected sample (9). These findings are indicative of a general lack of awareness particularly among smokers about the early signs of oral cancer. A need to initiate an oral-health promotion programme to educate the population regarding usefulness of mouth self-examination and early signs of oral cancer is warranted.

\section{CONCLUSION}

Oral leukoplakia was the most common OPMD among dental patients. A strong association exists between the prevalence of OPMDs and risk habits such as tobacco smoking and alcohol misuse. There was a general lack of awareness among smokers on the role of alcohol as an aetiological agent for oral cancer. Smokers also exhibited decreased awareness regarding early signs of oral cancer as compared to alcohol users alone.

\section{Acknowledgement}

We would like to thank all dental patients who participated in this study and staff at the primary care unit, Faculty of Dentistry, University of Malaya for the smooth conduct of the study.

\section{Declaration of interest}

The authors report no conflicts of interest. The authors alone are responsible for the content and writing of the paper.

\section{References}

1. Gonul M, Gul U, Kaya I, Kocak O, Cakmak SK, Kilic A, et al. Smoking, alcohol consumption and denture use in patients with oral mucosal lesions. J Dermatol Case Rep [Internet]. 2011;5(4):64-8. Available from: http://ovidsp. ovid.com/ovidweb.cgi?T=JS\&CSC $=$ Y\&NEW $\mathrm{S}=\mathrm{N} \& P A G E=$ fulltext $\& D=$ emed $10 \& A N=20116$ 94553\%5Cnhttp://openurl.ac.uk/athens:lee/? sid=OVID:embase\&id=pmid:\&id=doi: 10.3315 \%2Fjdcr.2011.1079\&issn=1898-7249\&isbn= \&volume $=5 \&$ issue $=4 \&$ spage $=64$ \& pages $=64-$ 68\&date $=2011 \&$ tit

2. Zain RB, Ikeda N, Razak I a, Axéll T, Majid Z a, GuptaPC, etal.Anationalepidemiological survey of oral mucosal lesions in Malaysia. Community Dent Oral Epidemiol. 1997;25(5):377-83.

3. Warnakulasuriya S, Johnson NW, Van Der Waal I. Nomenclature and classification of potentially malignant disorders of the oral mucosa. Vol. 36, Journal of Oral Pathology and Medicine. 2007. p. $575-80$.

4. Salahshourifar I, Vincent-Chong VK, Kallarakkal TG, Zain RB. Genomic DNA copy number alterations from precursor oral lesions to oral squamous cell carcinoma. Vol. 50, Oral Oncology. 2014. p. 404-12. 
5. Ahmadi-Motamayel F, Falsafi P, Hayati Z, Rezaei F, Poorolajal J. Prevalence of Oral Mucosal Lesions in Male Smokers and Nonsmokers. CChonnam Med J Chonnam Med J [Internet]. 2013;49:65-8. Available from: http://dx.doi. org/10.4068/cmj.2013.49.2.65

6. Campisi G, Margiotta V. Oral mucosal lesions and risk habits among men in an Italian study population. J Oral Pathol Med [Internet]. 2001;30(1):22-8. Available from: http://doi. wiley.com/10.1034/j.1600-0714.2001.300104.x

7. Control of oral cancer in developing countries. A WHO meeting. Bull World Health Organ [Internet]. 1984 [cited 2017 Jul 11];62(6):81730. Available from: http://www.ncbi.nlm.nih.gov/ pubmed/6335843

8. Warnakulasuriya KAAS, Harris CK, Scarrott DM, WattR, Gelbier S, Peters TJ, et al. oral cancer:An alarming lack of public awareness towards oral cancer. Br Dent J [Internet]. 1999;187(6):319_ 22. Available from: http://www.nature.com/ doifinder/10.1038/sj.bdj.4800269

9. Ghani WMN, Doss JG, Jamaluddin $M$, Kamaruzaman D, Zain RB. Oral cancer awareness and its determinants among a selected Malaysian population. Asian Pacific J Cancer Prev. 2013;14(3):1957-63.

10. Al Dubai SAR, Ganasegeran K, Alabsi AM, Alshagga MA, Ali RS. Awareness and knowledge of oral cancer among university students in Malaysia. Asian Pac J Cancer Prev [Internet]. 2012;13(1):165-8. Available from: http://www.ncbi.nlm.nih.gov/pubmed/22502661

11. Koay C, Lim J, Siar C. The prevalence of tongue lesions in Malaysian dental outpatients from the Klang Valley area. Oral Dis [Internet]. $2011 \mathrm{Mar}$ [cited $2017 \mathrm{Jul}$ 8];17(2):210-6. Available from: http://www.ncbi.nlm.nih.gov/pubmed/20796228
12. Napier SS, Speight PM. Natural history of potentially malignant oral lesions and conditions: An overview of the literature. Vol. 37, Journal of Oral Pathology and Medicine. 2008. p. 1-10.

13. Lin HC, Corbet EF, Lo EC. Oral mucosal lesions in adult Chinese. J Dent Res. 2001;80(5):148690.

14. Ariyawardana A, Vithanaarachchi N. Awareness of oral cancer and precancer among patients attending a hospital in Sri Lanka. Asian Pacific J Cancer Prev. 2005;6(1):58-61.

15. Carter LM, Ogden GR. Oral cancer awareness of general medical and general dental practitioners. $\mathrm{Br}$ Dent J. 2007;203(5):E10; discussion 248-249.

16. Rogers SN, Hunter R, Lowe D. Awareness of oral cancer in the Mersey region. $\mathrm{Br} \mathrm{J}$ Oral Maxillofac Surg. 2011;49(3):176-81.

17. Elango KJ, Anandkrishnan N, Suresh A, lyer SK, Ramalyer SK, Kuriakose MA. Mouth selfexamination to improve oral cancer awareness and early detection in a high-risk population. Oral Oncol [Internet]. $2011 \mathrm{Jul}$ [cited $2017 \mathrm{Jul}$ 8];47(7):620-4. Available from: http://www.ncbi. nIm.nih.gov/pubmed/21646040

\section{Corresponding author:}

\section{Assoc Prof. Dr. Thomas George Kallarakkal}

Department of Oral \& Maxillofacial Clinical Sciences

Faculty of Dentistry, University Malaya

50603 Kuala Lumpur.

Tel: 0379674808

Email: thomasg22@um.edu.my 